Reprod. Nutr. Dévelop., 1987, 27 (2 B), 471-480.

\title{
Effects of hypothalamic hormones (GRF, TRH, Somatostatin) and insulin-like growth factor I on growth hormone secretion from prepubertal male lamb pituitary cultures
}

\author{
Monique M. BLANCHARD (1), Cynthia G. GOODYER (*), J. CHARRIER, \\ J.-P. DULOR, B. BARENTON
}

with the technical collaboration of Véronique GARANDEL and A. FRAYSSE

Station de Physiologie animale, I.N.R.A.-E.N.S.A.M., 34060 Montpellier Cedex, France.

(*) Institut de Recherche de I'Université McGill.

Hopital de Montréal pour Enfants,

Montréal, Québec, Canada.

Summary. We have examined the regulation of $\mathrm{GH}$ secretion from monolayer cultures of prepubertal male lamb anterior pituitary cells. Growth hormone-releasing factor (GRF 1-44) stimulated $\mathrm{GH}$ release in a dose-related manner : the maximal effective dose was $10^{-10} \mathrm{M}$, which caused a $500 \%$ increase in basal GH secretion, while the half-maximal effect was reached with a dose of $2.5 \times 10^{-11} \mathrm{M}\left(E D_{50}\right)$. Thyrotropin-releasing hormone (TRH) also elicited a dose-dependent stimulation of $\mathrm{GH}$ secretion, although it was approximately 1000 times less potent than GRF. GRF and TRH did not have additive or synergistic effects on $\mathrm{GH}$ secretion.

Somatostatin (SRIF) at a concentration of $10^{-7} \mathrm{M}$ maximally inhibited basal GH release to $40 \%$ of that of the control ; the $\mathrm{ED}_{50}$ was $2.0 \times 10^{-9} \mathrm{M}$. Moreover, $10^{-7} \mathrm{M}$ SRIF blocked the stimulation of $\mathrm{GH}$ secretion induced by $10^{-8} \mathrm{M}$ GRF. However, when the cells were incubated with these two peptides at an identical concentration $\left(10^{-8} \mathrm{M}\right), \mathrm{GH}$ secretion was stimulated significantly above control values. When added at the same concentration $\left(10^{-7} \mathrm{M}\right)$, TRH and SRIF nullified their respective effects. A dose of $100 \mathrm{ng} / \mathrm{ml}$ of synthetic IGF-I was without effect on basal $\mathrm{GH}$ release, but significantly decreased $10^{-9} \mathrm{M}$ GRFinduced stimulation of $\mathrm{GH}$ secretion.

These data indicate that in prepubertal male lambs : (1) the stimulatory effect of GRF is predominant over the inhibitory effect of SRIF, (2) somatostatin inhibits TRH stimulation of $\mathrm{GH}$ secretion in vitro, and (3) IGF-I may control GH secretion by modulating GRF effects at the pituitary level.

\section{Introduction.}

Two hypothalamic hormones, growth hormone-releasing factor (GRF) and growth hormone release-inhibiting factor (SRIF), are known to be of major importance in regulating growth hormone $(\mathrm{GH})$ secretion in a variety of animal

(1) Address correspondence to : I.N.R.A.-E.N.S.A.M. Station de Physiologie animale, 34060 Montpellier Cedex France. 
species, including man. In normal humans, thyrotropin-releasing hormone (TRH) regulates TSH secretion but does not modify $\mathrm{GH}$ secretion (Anderson et al., 1971). A stimulatory effect of TRH on $\mathrm{GH}$ secretion in vivo and in vitro has been shown in chickens (Leung and Taylor, 1983), acromegalic patients (Jialal et al., 1984), and hypothyroid rats (Szabo et al., 1984). Moreover, a synergistic interaction between TRH and GRF on GH secretion has recently been demonstrated in immature rat pituitary cultures (Welsh et al., 1986) and in cattle in vivo (Hodate et al., 1985) and in vitro (Ingram and Bicknell, 1986). These results suggest that, under certain conditions, TRH is also able to modulate $\mathrm{GH}$ secretion. In addition, numerous data support the concept that in humans and rats, insulin-like growth factors (IGFs) regulate $\mathrm{GH}$ secretion at the pituitary level by a negative feedback mechanism (Brazeau et al., 1982a ; Tannenbaum et al., 1983 ; Goodyer et al., 1984a ; Goodyer et al., 1986).

We have recently developed an ovine pituitary monolayer culture system in order to study the ontogeny of mechanisms which control $\mathrm{GH}$ secretion during fetal and post-natal life in sheep. In the present study, we have investigated the roles of GRF, TRH, SRIF and IGF-I, alone or in combination, in the regulation of $\mathrm{GH}$ secretion from prepubertal male lamb pituitary cells.

\section{Materials and methods.}

Materials. - Human synthetic somatocrinin, GRF 1-44 (SR 95228), and somatostatin, SRIF 1-14 (SR 9357), were provided by Sanofi (Montpellier, France). Recombinant human (Thr59)-IGF-I was purchased from Amersham (Buckinghamshire, England). Collagenase, hyaluronidase, deoxyribonuclease, Ham's F-10 culture medium, fetal bovine serum and TRH were all otained from Boehringer Laboratories (Mannheim, Germany). Egg albumin and bovine serum albumin were purchased from Sigma (St Louis, MO).

Preparation of cells for monolayer culture. - The pituitary glands of four prepubertal male " Mérinos d'Arles " lambs, removed immediately after slaughter, were placed in Ham's F-10 with antibiotics and processed individually for monolayer culture. The anterior lobes were separated from the posterior and intermediate lobes and minced with sterile scissors. The pituitary fragments were dispersed at $37{ }^{\circ} \mathrm{C}$ for 45 to $60 \mathrm{~min}$ in Ham's F-10 medium containing $1.5 \mathrm{mg} / \mathrm{ml}$ of collagenase, $0.5 \mathrm{mg} / \mathrm{ml}$ of hyaluronidase, $0.25 \mathrm{mg} / \mathrm{ml}$ of deoxyribonuclease and $3 \%$ egg albumin. Cell dispersion was augmented by triturating the fragments through a sterile Pasteur pipette. Once the dispersion was completed, the cells were harvested by centrifugation for $2 \mathrm{~min}$ at $400 \times \mathrm{g}$ and washed twice in Ham's F-10 medium containing $10 \%$ fetal bovine serum. The cells were then plated at a density of 50,000 cells/well in 12-well plastic tissue culture plates in Ham's F-10 supplemented with $10 \%$ fetal bovine serum and antibiotics $(5 \mu \mathrm{g} / \mathrm{ml}$ of amphotericin B, $200 \mathrm{IU} / \mathrm{ml}$ of penicillin $\mathrm{G}, 40 \mu \mathrm{g} / \mathrm{ml}$ of gentamycin sulfate). Cell cultures were incubated at $37^{\circ} \mathrm{C}$ in an humidified atmosphere with $5 \% \mathrm{CO}_{2}$ for 3 days before the experiments began. The media were changed daily after the first $48 \mathrm{~h}$. 
Experimental procedure. - Experimental incubations were performed on the fourth day of culture using Ham's F-10 culture medium supplemented with $1 \%$ bovine serum albumin. The cells were preincubated for one hour, then rinsed and incubated for $3 \mathrm{~h}$ in the presence or absence of the test factors : each dose was tested in duplicate. At the end of the 3-hour incubation period, culture media were collected and centrifuged for $2 \mathrm{~min}$ at $400 \times \mathrm{g}$ to remove any cellular material. The supernatants were kept at $-80^{\circ} \mathrm{C}$ until assayed for $\mathrm{OGH}$.

Ovine growth hormone radioimmunoassay. - Ovine GH was measured by specific radioimmunoassay using a double antibody separation method. Reagents were provided by the National Hormone and Pituitary Program (NIADDK, Bethesda, MD) with the exception of sheep anti-rabbit-gammaglobulin serum which was prepared in our laboratory. The sensitivity of the assay was $0.5 \mathrm{ng} / \mathrm{ml}$ and the intra-assay variation was $5 \%$. Appropriate samples were prescreened and then all samples were run in the same assay at the appropriate dilution.

Expression of the results. - Results were expressed as a percentage of the controls (mean $\pm \mathrm{SE}$ ). Data were statistically analysed using analysis of variance followed by Duncan's multiple-range test after logarithmic transformation. The $\mathrm{ED}_{50} \mathrm{~s}$ were calculated as described by Rodbard (1974).

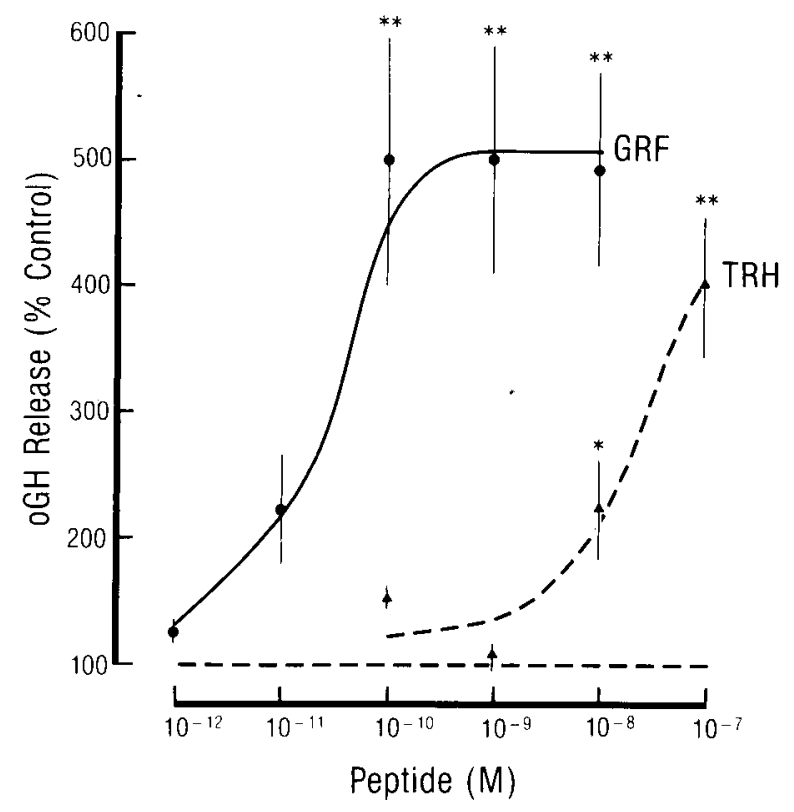

FIG. 1. - Dose-response curve of the effect of GRF or TRH on oGH release from cultured male lamb pituitary cells. Data are expressed as percent of control values (mean $\pm S E ; n=4){ }^{*} p<0.05$, ${ }^{* *} \mathrm{p}<0.01$ : statistical significance as compared to control values $(100 \%=9.31 \pm 1.54 \mathrm{ng} / \mathrm{ml} /$ $3 \mathrm{~h})$. 


\section{Results.}

Effect of GRF and TRH on $\mathrm{GH}$ release. - Basal $\mathrm{GH}$ secretion from cultured lamb pituitary cells was $9.31 \pm 1.54 \mathrm{ng} / \mathrm{ml} / 3 \mathrm{~h}$. The cells responded in a doserelated fashion to GRF $1.44\left(10^{-12} \mathrm{M}-10^{-8} \mathrm{M}\right)$ (fig. 1). Maximal stimulation occurred with a dose of $10^{-10} \mathrm{M}$, corresponding to an increase of $500 \%$ of basal $\mathrm{GH}$ secretion ( $p<0.01$ ). The half-maximal effect was obtained with a dose of $2.5 \times 10^{-11} \mathrm{M}\left(E D_{50}\right)$.

$\mathrm{TRH}$ also stimulated oGH release in a dose-dependent manner : the lowest effective dose $(\mathrm{p}<0.05)$ was $10^{-8} \mathrm{M}$, and a concentration of $10^{-7} \mathrm{M}$ caused a $400 \%$ increase in basal secretion ( $p<0.01$ ). The $\mathrm{ED}_{50}$ for $\mathrm{TRH}$ could not be determined since a maximal stimulation was not achieved. However, GRF was approximately 1,000 times more potent than $\mathrm{TRH}$ in stimulating $\mathrm{GH}$ release since the same effect was achieved with $10^{-11} \mathrm{M}$ GRF or $10^{-8} \mathrm{M} \mathrm{TRH}$.

Effect of somatostatin on $\mathrm{GH}$ release. - Somatostatin $\left(10^{-10} \mathrm{M}-10^{-6} \mathrm{M}\right)$ caused a dose-related inhibition of $\mathrm{GH}$ secretion (fig. 2). Hormone output was maximally decreased to $40 \%$ of its basal value with $10^{-7} \mathrm{M}$ SRIF ( $p<0.01$ ) : the $\mathrm{ED}_{50}$ was $2.0 \times 10^{-9} \mathrm{M}$.

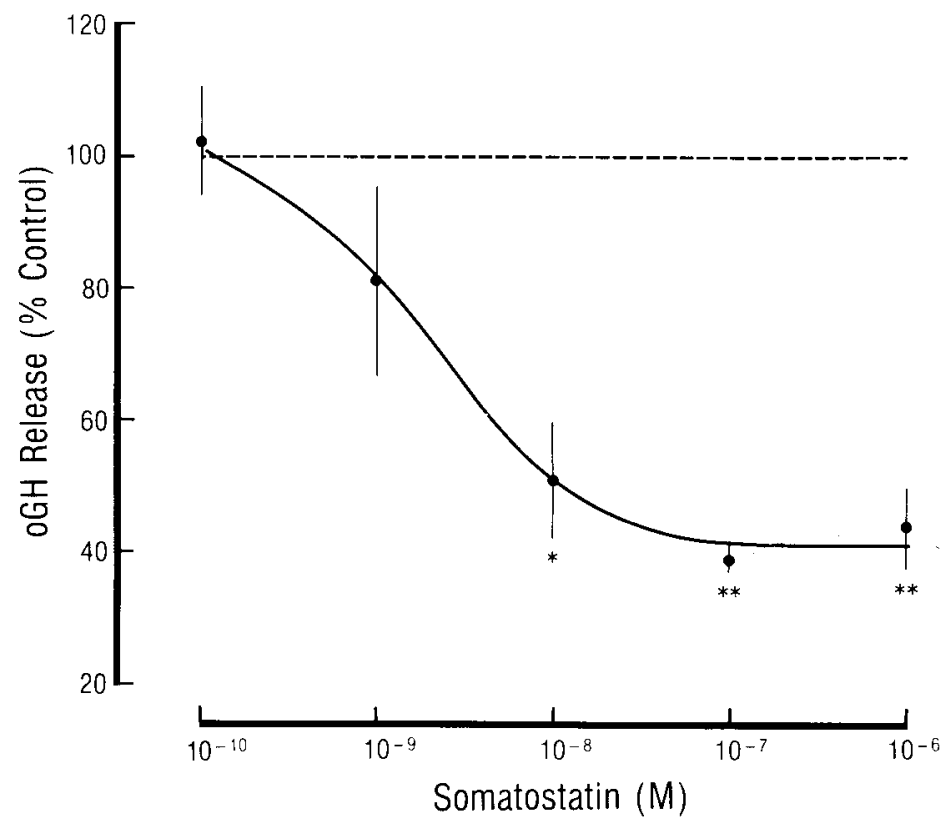

FIG. 2. - Dose-response curve of the effect of SRIF on oGH release from cultured male lambpituitary ce/ls. Data are expressed as percent of control values (mean $\pm S E ; n=4$ ) ${ }^{*} p<0.05$, ${ }^{*}{ }^{*} p<0.01$ : statistical significance as compared to control values $(100 \%=9.31+1.54 \mathrm{ng} / \mathrm{ml} /$ 3 h).

Effect of GRF $1-44$ plus somatostatin. - Figure 3 represents two different experiments showing the effect of combining GRF and somatostatin. In the first experiment (fig. 3A), increasing doses of somatostatin $\left(10^{-10} \mathrm{M}-10^{-6} \mathrm{M}\right)$ were 
tested in the presence of a constant concentration of $10^{-8} \mathrm{M}$ GRF. A $10^{-7} \mathrm{M}$ dose of SRIF completely abolished GRF stimulation of GH secretion (from $492.2 \pm$ $84.9 \%$ to $95.5 \pm 19.5 \% ; p<0.01)$. When GRF and somatostatin were added to the cells at the same concentration $\left(10^{-8} \mathrm{M}\right)$, the resulting effect was a significant $(p<0.01)$ increase above basal GH secretion, indicating that the stimulatory effect of GRF on somatotrope activity was predominant over the inhibitory effect of SRIF in prepubertal lambs. In the second experiment (fig. 3B), a constant dose of $10^{-7} \mathrm{M}$ SRIF was added in combination with increasing concentrations of GRF ranging from $10^{-11}$ to $10^{-8} \mathrm{M}$. GRF blocked the inhibition induced by somatostatin but did not significantly increase oGH release above control values.
A. GRF $1-44\left(10^{-8} \mathrm{M}\right)$
B. SRIF $\left(10^{-i} M\right)$

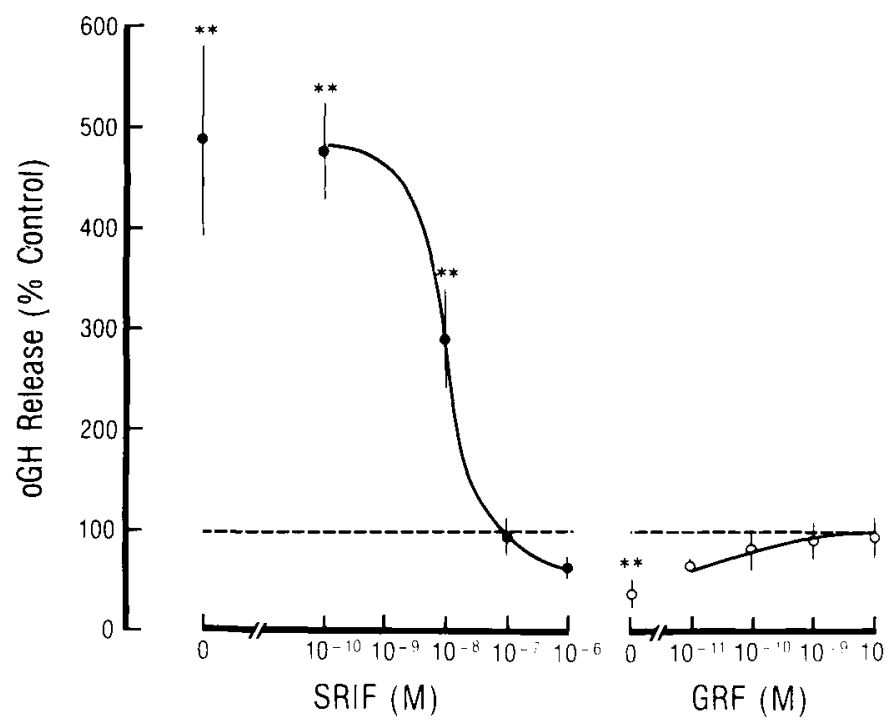

FIG. 3.-- Interactions of GRF and SRIF on OGH release from male lamb pituitary cells in culture : A. Effect of GRF $\left(10^{-8} \mathrm{M}\right)$ on SRIF $\left(10^{-10} \mathrm{M}-10^{-6} \mathrm{M}\right)$ inhibition of $\mathrm{GH}$ release, and B. Effect of SRIF $\left(10^{-7} \mathrm{M}\right)$ on GRF $\left(10^{-11} \mathrm{M}-10^{-8} \mathrm{M}\right)$ stimulation of $\mathrm{GH}$ release.

Data are expressed as percent of control values (mean $\pm \mathrm{SE} ; n=4$ ); ${ }^{*} p<0.01$ : statistical significance as compared to control values $(100 \%=9.31 \pm 1.54 \mathrm{ng} / \mathrm{ml} / 3 \mathrm{~h})$.

Effect of TRH plus GRF or somatostatin. - A constant dose of TRH $\left(10^{-7} \mathrm{M}\right)$ was tested in the presence of increasing concentrations of GRF $\left(10^{-12} \mathrm{M}\right.$ $10^{-8} \mathrm{M}$ ) or somatostatin $10^{-11} \mathrm{M}-10^{-7} \mathrm{M}$ ) (fig. 4). GRF did not significantly increase TRH stimulation of $\mathrm{GH}$ secretion. Furthermore, the response induced by $10^{-8} \mathrm{M}$ GRF plus $10^{-7} \mathrm{M}$ TRH was not significantly different from the effect of $10^{-8} \mathrm{GRF}$ alone. Thus, we did not observe any additive or synergistic effects of GRF and TRH on oGH secretion.

TRH-induced stimulation of GH release was markedly inhibited by SRIF (from $402.6 \pm 62.0 \%$ to $92.7 \pm 2.8 \% ; p<0.01)$. In contrast to what we observed 
with GRF and somatostatin, incubation of cells with the same dose of TRH and SRIF $\left(10^{-7} \mathrm{M}\right)$ did not modify basal $\mathrm{GH}$ secretion. These results indicate that, in prepubertal lambs, SRIF is able to completely block TRH stimulation of GH release at the pituitary level.

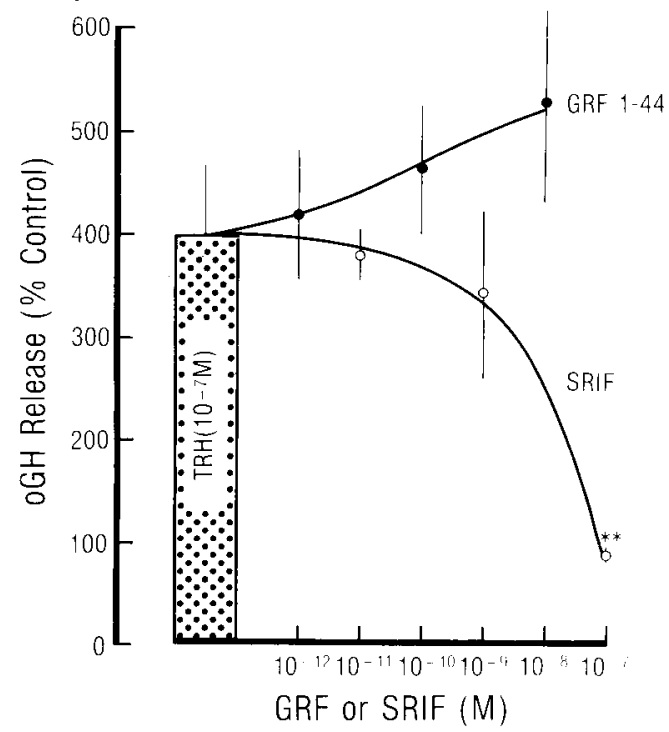

FIG. 4. - Interactions of TRH $\left(10^{-7} \mathrm{M}\right)$ with $G R F\left(10^{-12} \mathrm{M}-10^{-8} \mathrm{M}\right)$ or $S R / F\left(10^{-11} \mathrm{M}-10^{-7} \mathrm{M}\right)$ on $\mathrm{GH}$ secretion from cultured male lamb pituitary cells. Data are expressed as percent of control values (mean $\pm \mathrm{SE} ; \mathrm{n}=4)^{* *} \mathrm{p}<0.01$ : statistical significance as compared to $10^{-7} \mathrm{M}$ TRH $(100 \%=9.31 \pm 1.54 \mathrm{ng} / \mathrm{ml} / 3 \mathrm{~h})$.

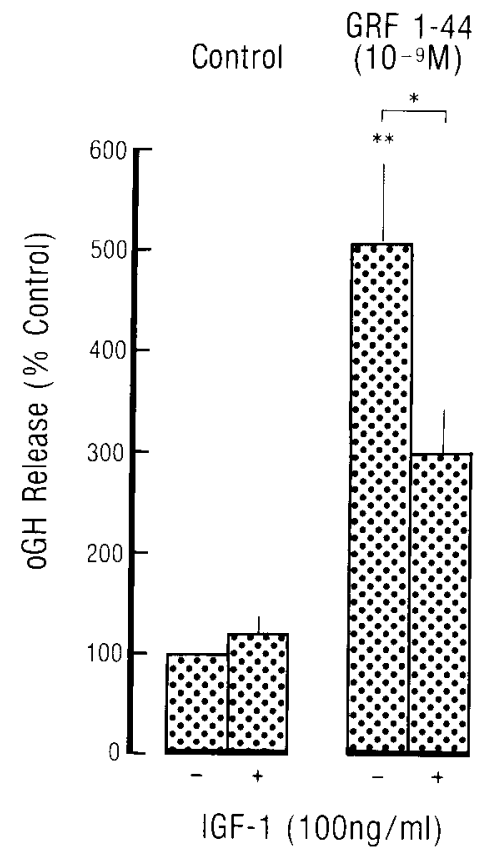

FIG. 5. - Effect of $/ G F-/(100 \mathrm{ng} / \mathrm{ml})$ on basal and GRF $\left(10^{-9} \mathrm{M}\right)-$ stimulated $G H$ secretion. Data are expressed as percent of control values (mean $\pm S E ; n=4$ ) ${ }^{*} p<0.01$ : statistical significance as compared to control values $(100 \%=10.6 \pm 1.97 \mathrm{ng} / \mathrm{ml} / 3 \mathrm{~h})$. 
Effect of IGF-I on basal and GRF-stimulated GH secretion. - Figure 5 shows that while $100 \mathrm{ng} / \mathrm{ml}$ of synthetic IGF-I did not modify basal GH secretion during the three-hour incubation period, GRF $\left(10^{-9} \mathrm{M}\right)$-stimulated release of $\mathrm{GH}$ was significantly decreased (from $508.04 \pm 82.05 \%$ to $299.68 \pm 46.23 \% ; p<0.05$ ).

\section{Discussion.}

Our results indicating that GRF is a potent stimulator of $\mathrm{GH}$ release from cultured pituitary cells of prepubertal male lambs are in agreement with in vitro pituitary data on lambs from Law et al. (1984). They also correlate with the finding that GRF stimulates $\mathrm{GH}$ release in prepubertal male lambs in vivo (Barenton et al., 1987). The GRF dose-response curve for these cells is similar to that observed in studies using adult male rat pituitary cultures (Brazeau et al., 1982b).

We also found that somatostatin can inhibit basal as well as GRF-stimulated $\mathrm{GH}$ secretion, although the cells appear to be more sensitive to GRF than to SRIF : that is, in prepubertal lambs, the effect of GRF on GH secretion is predominant over the effect of SRIF when the same concentrations are tested. A similar phenomenon has been reported in studies using fetal human pituitary explants (Goodyer et al., 1984b; Goodyer et al., 1987), while the opposite phenomenon has been observed with adult rat pituitary cultures (Law et al., 1985). These discrepancies may be due to species differences or to changes in the relative potencies of GRF and SRIF during development.

We have also clearly shown that TRH stimulates $\mathrm{GH}$ release from lamb pituitary cell cultures, even though it is much less effective than GRF. It is unlikely that TRH acts through the GRF receptor since the respective structures of the two peptides are so different. On the other hand, the existence of two different populations of specific receptors for GRF and TRH on the somatotrophs (as shown for human pituitary adenomas : Le Dafniet et al., 1985) would imply that submaximal doses of GRF and TRH have additive effects on $\mathrm{GH}$ secretion. We did not observe any additive or synergistic effects with the two peptides, but the elevated dose of $\mathrm{TRH}\left(10^{-7} \mathrm{M}\right)$ we used in these experiments may have masked certain subtle interactions. These data suggest that a common final pathway may be involved in GRF and TRH action mechanisms. Further experiments will be required to elucidate the physio!ogic significance of the action of $\mathrm{TRH}$ on $\mathrm{GH}$ secretion in lambs.

We have also demonstrated that SRIF is able to abolish $\mathrm{TRH}$-induced stimulation of $\mathrm{GH}$ release in vitro. It is noteworthy that, in contrast to what we observed with GRF and SRIF, the addition of equivalent doses of TRH and SRIF to the cells resulted in a complete blockade of the effect of TRH. Wrutniak et al. (1987) did not observe any in vivo effect of TRH on $\mathrm{GH}$ secretion in lambs. These findings suggest that, in vivo, endogenous somatostatin might inhibit response to TRH by blocking its effect at the pituitary level.

Growth hormone has no single well-defined target organ, but has been shown to induce the hepatic production of somatomedins (Uthne and Uthne, 
1972 ; Schimpff et al., 1976; Binoux et al., 1980) which may mediate the peripheral effects of $\mathrm{GH}$ (Froesch et al., 1985). Clinical and experimental observations have led to the concept of a role for the somatomedins in controlling $\mathrm{GH}$ secretion by a negative feedback loop on the pituitary and hypothalamus. Low levels of IGFs are often associated with high levels of GH (Zapf et al., 1976). IGFs suppress the episodic bursts of $\mathrm{GH}$ when injected intraventricularly into freely-moving rats (Tannenbaum et al., 1983). Recently, Yamashita and Melmed (1986) showed that IGF-I inhibits GH synthesis by decreasing GH mRNA levels.

We did not see any effect of IGF-I on basal GH secretion in our experiment, although we used a pure peptide in a defined medium. Goodyer et al. (1984a ; 1986) reported an effect of $100 \mathrm{ng} / \mathrm{ml}$ of purified IGF-I on basal GH secretion from adult rat and fetal human pituitary explants after 3-4 h while Brazeau et al. (1982a) observed the same effect at a lower dose but after 20 hours of incubation. Results may differ, depending on the species, dose, length of incubation or the origin of the peptide used.

In contrast, IGF-I decreased GRF-induced stimulation of GH release. These data are consistent with previous observations with rat pituitary monolayers (Brazeau et al., 1982a). They support the hypothesis that IGF-I can exert a negative feedback inhibition of oGH synthesis and/or release by modulating the effect of GRF on somatotrope activity in prepubertal lambs. Further studies will be necessary to determine the role for somatomedins during fetal and post-natal development in sheep.

12e Réunion du groupe Développement I.N.R.A., Montpellier, 28-30 mai 1986.

Acknowledgements. - This study was supported by Sanofi (Grant \# 9532 B).

Résumé. Effet des hormones hypothalamiques (GRF, TRH, somatostatine) et du facteur de croissance (IGF-ll) sur la sécrétion de la GH par des cultures d'hypophyse d'agneau mâle prépubère.

Nous avons étudié la régulation de la sécrétion de l'hormone de croissance par les cellules hypophysaires ovines en culture primaire. Le GRF 1-44 stimule la libération de la GH de façon dose-dépendante : l'effet maximum est atteint avec une concentration de $10^{-10} \mathrm{M}$ de GRF, et représente une augmentation de $500 \%$ de la sécrétion basale. La dose qui induit $50 \%$ de l'effet maximum $\left(\mathrm{ED}_{50}\right)$ est de $2,5 \times 10^{-11} \mathrm{M}$. La thyréolibérine (TRH) entraîne également une stimulation de la sécrétion de $\mathrm{GH}$, bien que la sensibilité des cellules vis-àvis de la TRH soit environ 1000 fois plus faible que celle vis-à-vis du GRF. Les effets du GRF et de la TRH sur la sécrétion de GH ne sont ni additifs, ni synergiques. La somatostatine inhibe la libération basale de $\mathrm{GH}$ de $60 \%$ à la dose de $10^{-7} \mathrm{M}: \mathrm{I}^{\prime} E D_{50}$ est de $2,0 \times$ $10^{-9} \mathrm{M}$. De plus, la stimulation de la sécrétion de $\mathrm{GH}$ induite par $10^{-8 \mathrm{M}}$ de GRF est bloquée par $10^{-7} \mathrm{M}$ de somatostatine. Cependant, quand on incube les cellules en présence de ces deux peptides à concentration égale $\left(10^{-8} \mathrm{M}\right)$, l'effet résultant observé est une stimulation de la libération de GH. Par ailleurs, les effets de la TRH et du SRIF s'annulent quand les cellules sont incubées avec les deux peptides à la même concentration. Enfin, une dose de $100 \mathrm{ng} / \mathrm{ml}$ d'IGF-I synthétique est sans effet sur la libération basale de $\mathrm{GH}$, mais diminue la stimulation induite par $10^{-9} \mathrm{M}$ de GRF. 
Ces résultats indiquent que chez l'agneau mâle prépubère : 1) l'effet stimulant du GRF prédomine sur l'effet inhibiteur de la somatostatine ; 2) la somatostatine inhibe la stimulation de la sécrétion de GH induite par la TRH in vitro ; et 3) IGF-I pourrait participer au contrôle de la sécrétion de la $\mathrm{GH}$, en modulant I'action du GRF au niveau de I'hypophyse.

\section{Références}

ANDERSON M. S., BOWERS C. Y., KASTIN A. J., SCHALCH D. S., SCHALLY A. V., SNYDER P. J., UTIGER R. D., WILBER J. F., WISE A. J., 1971. Synthetic thyrotropin-releasing hormone. New Engl. J. Med., 285, 1279-1281.

BARENTON B., DUCLOS M., DIAZ J., DELETANG F., DULOR J. P., BLANCHARD M. M., CHARRIER J., 1987. Characteristics of growth hormone response to the administration of growth hormone-releasing factor (GRF) in the lamb. Reprod. Nutr. Dévelop., 27, 491-500.

BINOUX M., HOSSENLOPP P., LASSARRE C., SEURIN D., 1980. Somatomedin production by rat liver in organ culture. Acta Endocrinol., 93, 73-82.

BRAZEAU P., GUILLEMIN R., LING N., VAN WYK J., HUMBEL R., 1982a. Inhibition par les somatomédines de la sécrétion de l'hormone de croissance stimulée par le facteur hypothalamique somatocrinine (GRF) ou le peptide de synthèse hpGRF. C. R. Acad. Sci. Paris, 295, $651-654$.

BRAZEAU P., LING N., BÖHLEN P., ESCH F., YING S., GUILLEMIN R., 1982b. Growth hormone-releasing factor, somatocrinin, releases pituitary growth hormone in vitro. Proc. nat. Acad. Sci. USA, 79, 7909-7913.

FROESCH E. R., SCHMID C. H. R., SCHWANDER J., ZAPF J., 1985. Actions of insulin-like growth factors. Ann. Rev. Physiol., 47, 443-467.

GOODYER C. G., DE STEPHANO L., GUYDA H. J., POSNER B. I., 1984a. Effects of insulin-like growth factors on adult male rat pituitary function in tissue culture. Endocrinology, 115, 15681576.

GOODYER C. G., MARCOVITZ S., BEREZUIK M., DE STEPHANO L., LEFEBVRE Y., 1984b. In vitro modulation of $\mathrm{GH}$ secretion from early gestation human fetal pituitaries. In : Fetal neuroendocrinology, F. ELLENDORF, P. D. GLUCKMAN, N. PARVIZI, Perinatology Press, Ithaca, New York, 209-212.

GOODYER C. G., MARCOVITZ S., HARDY J., LEFEBVRE Y., GUYDA H. J., POSNER B. I., 1986. Effect of insulin-like growth factors on human fetal, adult normal and tumor pituitary function in tissue culture. Acta endocrinol., 112, 49-57.

GOODYER C. G., SELLEN J. M., FUKS M., BRANCHAUD C., MARCOVITZ S., LEFEBVRE Y., 1987. Regulation of GH secretion from human fetal pituitaries. Reprod. Nutr. Dévelop., 27, $461-470$.

HODATE K., JOHKE T., OHASHI S., 1985. Growth hormone, thyrotropin and prolactin responses to simultaneous administration of human growth hormone-releasing factor and thyrotropinreleasing hormone in the bovine. Endocrinol. japon., 32, 375-383.

INGRAM L. D., BICKNELL R. J., 1986. Synergistic interactions in bovine pituitary cultures between GRF and other hypophysiotropic factors. J. Endocr., 109, 67-74.

JIALAL I., NAIDOO C., NATHOO B. C., RAJPUT M. C., JOUBERT S. M., 1984. The growth hormone responses to L-dopa and TRH in acromegaly. J. endocrinol. Invest., 7, 235237.

LAW G. J., RAY K. P., WALLIS M., 1984. Effects of growth hormone-releasing factor, somatostatin and dopamine on growth hormone and prolactin secretion from cultured ovine pituitary cells. FEBS Letters, 166, 189-193.

LAW G. J., KEITH P. R., WALLIS M., 1985. Effects of growth hormone-releasing factor and somatostatin on growth hormone secretion and cellular cyclic AMP levels. FEBS Letters, 179, $12-16$.

LE DAFNIET M., GARNIER P., BRESSION D., BRAUDI A. M., RACADOT J., PEILLON F., 1985. Correlative studies between the presence of thyrotropin-releasing hormone $(T R H)$ receptors and the in vitro stimulation of growth hormone $(\mathrm{GH})$ secretion in human $\mathrm{GH}$-secreting adenomas. Horm. Metab. Res., 17, 476-479. 
LEUNG F. C., TAYLOR J. E., 1983. In vivo and in vitro stimulation of growth hormone release in chickens by synthetic human pancreatic growth hormone-releasing factor (hpGRFs). Endocrinology, 113, 1913-1915.

RODBARD D., 1974. Apparent positive cooperative effects in cyclic AMP and corticosterone production by isolated adrenal cells in response to ACTH analogues. Endocrinology, 94, 14271437.

SCHIMPFF R. M., DONNADIEU M., GLASINOVIC J. C., WARNET J. M., GIRARD F., 1976. The liver as a source of somatomedin ; an in vivo study in the dog. Acta endocrinol., 83, 365-372.

SZABO M., STACHURA M. E., PALEOLOGOS N., BYBEE D. E., FROHMAN L. A., 1984. Thyrotropin-releasing hormone stimulates growth hormone release from the anterior pituitary of hypothyroid rats in vitro. Endocrinology, 114, 1344-1351.

TANNENBAUM G. S., GUYDA H. J., POSNER B. I., 1983. Insulin-like growth factors : a role in growth hormone negative feedback and body weight regulation. Science, 220, $77-79$.

UTHNE K., UTHNE T., 1972. Influence of liver resection and regeneration on somatomedin (sulfation factor) activity in sera from normal and hypophysectomized rats. Acta endocrinol., 71, 255264.

WELSH J. B., CUTTLER L., SZABO M., 1986. Ontogeny of the in vitro growth hormone stimulatory effect of thyrotropin-releasing hormone in the rat. Endocrinology, 119, 2368-2375.

WRUTNIAK C., CABELLO G., CHARRIER J., DULOR J. P., BLANCHARD M., BARENTON B., 1987. Effects of TRH and GRF administration on GH, TSH, T4 and T3 secretion in the lamb. Reprod. Nutr. Dévelop., 27, 501-510.

YAMASHITA S., MELMED S., 1986. Insulin-like growth factor I action on rat anterior pituitary cells : Suppression of growth hormone secretion and messenger ribonucleic acid levels. Endocrinology, 118, 176-182.

ZAPF J., MORELL B., WALTER H., LARON Z., FROESCH E. R., 1976. Serum levels of insulinlike Growth Factor (IGF) and its carrier protein in various metabolic disorders. Acta endocrinol., 95, 505-517. 